\title{
MIR17HG Gene
}

National Cancer Institute

\section{Source}

National Cancer Institute. MIR17HG Gene. NCI Thesaurus. Code C118113.

This polycistronic gene locus is located in the vicinity of $13 \mathrm{q} 31.3$ and is approximately $7 \mathrm{~kb}$ in length. This locus encodes at least six microRNA genes. Microdeletions within this locus are associated with Feing old syndrome 2. Amplification of this locus may be associated with various cancers. 